\title{
KARAKTERISASI ENAM VARIETAS BUNCIS (Phaseolus vulgaris L.) BERDASARKAN PANDUAN PENGUJIAN INDIVIDUAL
}

\section{CHARACTERIZATION SIX VARIETIES BEANS (Phaseolus vulgaris L.) BY GUIDELINES FOR THE CONDUCT OF TEST}

\author{
Vina Eka Aristya ${ }^{1}$ dan Intan Gilang Cempaka ${ }^{2}$
}

Diterima 26 Juni 2012, disetujui28 Juni 2013

\begin{abstract}
Beans (Phaseolus vulgaris L.) is a plant that has the potential for mainstream consumers, have a large enough market opportunity and a source of vegetable protein. "Perancis" varieties are local Central Java bean varieties are widely grown in the Bandungan area. "Perancis" varieties not currently provide enough characters clear and complete. Test objectives were (1) to characterize the "Perancis" varieties in order to have a complete character information varieties and (2) to determine distinctness, uniformity and stability of the "Perancis" varieties compared with varieties Gypsie, Spectacular, Balitsa 1, Balitsa 2 and PV 072 using guidelines for the conduct of test for distinctness, uniformity and stability reference beans. Implemented on the Garden Seed Testing Bandungan Horticulture, Central Java with an altitude of 560-800 meters above sea level the place. Materials testing consists of six varieties of beans are "Perancis" varieties and the varieties used for comparison Gypsie, Spectacular, Balitsa 1, Balitsa 2 and PV 072. This research used a randomized block design six varieties of beans are planted side by side on three experimental plots as replications. Parameters observed include 49 characters corresponding guidelines bean plants are divided into the plant character, leaves character, flower character, pods character and seed character. Test results based guidelines, "Perancis" varieties showed eight unique characters compared to varieties of Gypsie, Spectacular, Balitsa 1, Balitsa 2 and PV 072 ie. plant height, leaf color, leaf rugosity, long (including beak) pods, the degree of the pods curvature, the shape of distal part (excluding beak) pods, length of beak pods and curvature of beak pods and "Perancis" varieties have uniformity and stability.
\end{abstract}

Key words : Phaseolus vulgaris L., beans, characterization.

\section{PENDAHULUAN}

Aneka kacang merupakan salah satu sumber protein nabati yang dapat diproduksi dan disediakan dengan mudah dan murah dibandingkan dengan protein hewani (Djuariah, 2008). Buncis (Phaseolus vulgaris L.) merupakan sayuran yang berpotensi ekonomi tinggi karena mempunyai peluang pasar yang cukup luas dan merupakan salah satu sumber protein nabati yang murah dan mudah dikembangkan (Rismunandar, 1982). Polong

\footnotetext{
1,2 Balai Pengkajian Teknologi Pertanian Jawa Tengah Bukit Tegalepek, Sidomulyo, Kotak Pos 101, Ungaran 50501 Telp. (024) 6924965 Fax. (024) 6924966

e-mail : vinaaristya@gmail.com
}

buncis sangat digemari konsumen karena rasanya enak dan gurih (Sunarjono, 2007). Tanaman kacang buncis merupakan salah satu tanaman sayuran yang penting karena memiliki kandungan gizi cukup tinggi. Setiap 100 gram kacang buncis mengandung 35.00 kalori, 2.4 gram protein, 0.2 gram lemak, 7.4 gram karbohidrat, $65 \mathrm{mg}$ kalsium, 44 gram fosfor, 1.1 gram besi, vitamin A 630 SI, serta vitamin B $0.8 \mathrm{mg}$, vitamin C 19 mg dan air 88.9 gram (Anonim, 1981).

Varietas adalah sekelompok tanaman dari suatu jenis atau spesies yang ditandai oleh bentuk dan pertumbuhan tanaman, daun, bunga, buah, biji dan ekspresi karakter atau kombinasi genotip 
yang dapat membedakan dengan jenis atau spesies yang sama oleh sekurang-kurangnya satu sifat yang menentukan dan apabila diperbanyak tidak mengalami perubahan (Departemen Pertanian 2002). Berdasarkan definisi tersebut maka suatu varietas dapat dibedakan berdasarkan karakter yang dimilikinya.

Varietas "Perancis" merupakan varietas buncis lokal Jawa Tengah yang banyak berkembang di daerah Bandungan, yang saat ini belum memberikan informasi karakter yang cukup jelas dan lengkap, hanya mendeskripsikan beberapa karakter, yaitu merupakan buncis dengan tipe pertumbuhan tegak atau bush bean dengan karakteristik tanaman yang tidak memerlukan turus karena tidak merambat, habitus tanaman rimbun terdukung oleh percabangan yang berselang dekat dan bunga mekar relatif lebih serempak. Varietas "Perancis" merupakan sayuran jenis kacang-kacangan dengan bentuk lebih bulat dan ukurannya lebih kecil dan rasanya lebih manis ketika disantap.

Menurut Kusmana dan Sofiari (2007), pendeskripsian yang kurang jelas dan kurang lengkap dapat menyebabkan ketidakpastian keberadaan suatu varietas. Pusat Perlindungan Varietas Tanaman (2007) mengeluarkan Panduan Pengujian Individual komoditas buncis (PPI Buncis) dengan nomor PVT/PPI/20/1 yang memuat 49 karakter yang diamati, dimana sebagian dari karakter tersebut harus diamati agar dapat diketahui keunikan, keseragaman dan kestabilan suatu varietas.

Tujuan pengujian adalah (1) untuk mengkarakterisasi varietas "Perancis" agar didapatkan informasi karakter varietas yang lengkap, dan (2) untuk mengetahui keunikan, keseragaman dan kestabilan varietas "Perancis" dibandingkan dengan varietas Gypsi, Spektakuler, Balitsa 1, Balitsa 2 dan PV 072 menggunakan acuan PPI buncis.

\section{METODOLOGI}

Pengujian dilaksanaan di Kebun Benih Hortikultura Bandungan, Jalan Sukorini No. 28, dusun Karanglo, desa Kenteng, kecamatan Bandungan, kabupaten Semarang, Jawa Tengah. Ketinggian tempat 560-800 m dpl, dengan suhu minimal $16-18^{\circ} \mathrm{C}$ dan suhu maksimal $28-30^{\circ} \mathrm{C}$, curah hujan $2300 \mathrm{~mm} /$ tahun, jenis tanah Andosol, serta pH 5-7. Pengujian berlangsung pada bulan Juni-September 2012. Bahan pengujian terdiri atas enam varietas buncis yaitu varietas "Perancis" dan sebagai pembandingnya digunakan varietas Gypsi, Spektakuler, Balitsa 1, Balitsa 2 dan PV 072. Enam varietas buncis ditanam berdampingan pada tiga petak percobaan sebagai ulangan menggunakan rancangan acak kelompok. Petak percobaan berisi 150 tanaman, 20 diantaranya dipakai untuk pengamatan stadia vegetatif dan 20 lainnya dipakai untuk pengamatan stadia generatif.

Penanaman buncis diawali dengan kegiatan penyiapan benih sebanyak $1000 \mathrm{~g}$ yang memenuhi syarat daya kecambah tinggi dan kemurnian varietas. Kultur teknis meliputi pengolahan lahan karena buncis membutuhkan tanah yang gembur, penanaman dengan jarak tanam $20 \mathrm{~cm} \times 40 \mathrm{~cm}$, pemeliharaan yang terdiri dari: penyulaman; pengairan; pemupukan susulan; penyiangan; roguing, serta pengendalian hama dan penyakit berdasarkan keadaan pertanaman di lapang. Parameter yang diamati mencakup 49 karakter sesuai PPI buncis yang terbagi menjadi karakter tanaman, daun, bunga, polong dan biji.

Penilaian keseragaman populasi ditetapkan standar 1 persen untuk buncis tipe tegak dengan peluang diterima 95 persen, untuk populasi 150 tanaman makajumlah tipe simpang maksimum yang diperbolehkan adalah empat. Pengamatan terhadap perilaku tumbuh dan karakter daun dilakukan pada waktu berbunga penuh. Pengamatan polong dilakukan pada waktu polong masak segar yang siap dipasarkan. Pengamatan biji dilakukan pada biji kering yang 
dipanen dari petak percobaan. Penilaian kestabilan didasarkan pada banyak tipe varietas, jika satu varietas telah menunjukkan keseragaman maka telah dianggap stabil.

\section{HASIL DAN PEMBAHASAN}

\section{Keunikan}

Hasil karakterisasi buncis varietas "Perancis", Gypsi, Spektakuler, Balitsa 1, Balitsa 2 dan PV 072 ditunjukkan pada tabel 1. Hasil pengujian menunjukkan delapan karakter keunikan varietas "Perancis" dibandingkan dengan varietas Gypsi, Spektakuler, Balitsa 1, Balitsa 2 dan PV 072 antara lain pada karakter tanaman, karakter daun dan karakter polong.

\section{Karakter Tanaman}

Tanaman buncis dapat tumbuh baik bila ditanam di dataran tinggi (Estu dan Nur, 1994). Kacang buncis tipe tegak di Indonesia merupakan tanaman sayuran yang spesifik dataran tinggi. Biasanya diusahakan di daerah-daerah dengan ketinggian 500-1500 mdpl (Pinilih, 2005). Varietas "Perancis" termasuk buncis tipe tegak, terdapat pewarnaan antosianin pada hipokotil dan tidak memuntir yang banyak berkembang di daerah Bandungan, Jawa Tengah. Pada pengujian didapatkan keunikan varietas "Perancis" pada karakter tinggi tanaman yaitu $49.4 \mathrm{~cm}$ dengan notasi 5 (sedang) jika dibandingkan dengan varietas PV 072 yaitu 34 cm dengan notasi 3 (pendek).

\section{Karakter Daun}

Karakter daun buncis yang diamati adalah warna daun, kerutan, ukuran anak daun terminal, bentuk anak daun terminal dan ujung anak daun terminal. Secara prinsip terdapat dua perbedaan karakter daun antara varietas "Perancis" dengan varietas pembanding yaitu warna daun dan kerutan daun. Varietas "Perancis" memiliki warna daun dengan notasi 9 (sangat gelap) dibandingkan varietas Gypsi dengan notasi 5 (medium), serta varietas
Balitsa 1 dan Balitsa 2 dengan notasi 7 (gelap). Sedangkan hasil pengujian karakter kerutan daun menunjukkan perbedaan, varietas "Perancis" memiliki kerutan daun lemah (notasi 3) sedangkan varietas Gypsi, Spektakuler dan Balitsa 1 memiliki kerutan daun kuat (notasi 7).

\section{Karakter Bunga}

Pengamatan umur tanaman berbunga rata-rata dilakukan pada saat 50 persen dari jumlah tanaman setiap petak percobaan yang telah berbunga penuh. Rata-rata umur berbunga semua kultivar buncis berkisar antara 28 hari - 35 hari. Karakter bunga buncis yang diamati meliputi posisi tandan bunga saat bunga mekar, ukuran braktea, warna standar dan warna sayap. Varietas "Perancis" menunjukkan diskripsi posisi tandan bunga saat bunga mekar ada di bawah tajuk, ukuran braktea sedang, warna standar ungu dan warna sayap ungu yang berarti tidak menunjukkan perbedaan dengan varietas pembandingnya.

Menurut Pinilih (2005) sifat warna bunga dikendalikan oleh satu gen dominan, sifat warna bunga dalam pewarisannya tidak dipengaruhi oleh keadaan lingkungan, walaupun ada perubahan, wama dasamya akan tetap ungu atau putih. Faktor lingkungan seperti panjang hari atau fotoperiodisitas dan suhu sangat mempengaruhi faktor pembungaan.

\section{Karakter Polong}

Polong merupakan karakter penting pada buncis karena memiliki nilai ekonomi yang tinggi. Perbedaan karakter polong antara varietas "Perancis" dengan varietas pembandingnya adalah panjang (termasuk paruh) polong, derajat kelengkungan polong, bentuk bagian ujung (tidak termasuk paruh) polong, panjang paruh polong dan lengkungan paruh polong.

Pengamatan karakter panjang (termasuk paruh) polong buncis tipe tegak varietas "Perancis" menunjukkan notasi 7 (panjang) berbeda dengan 


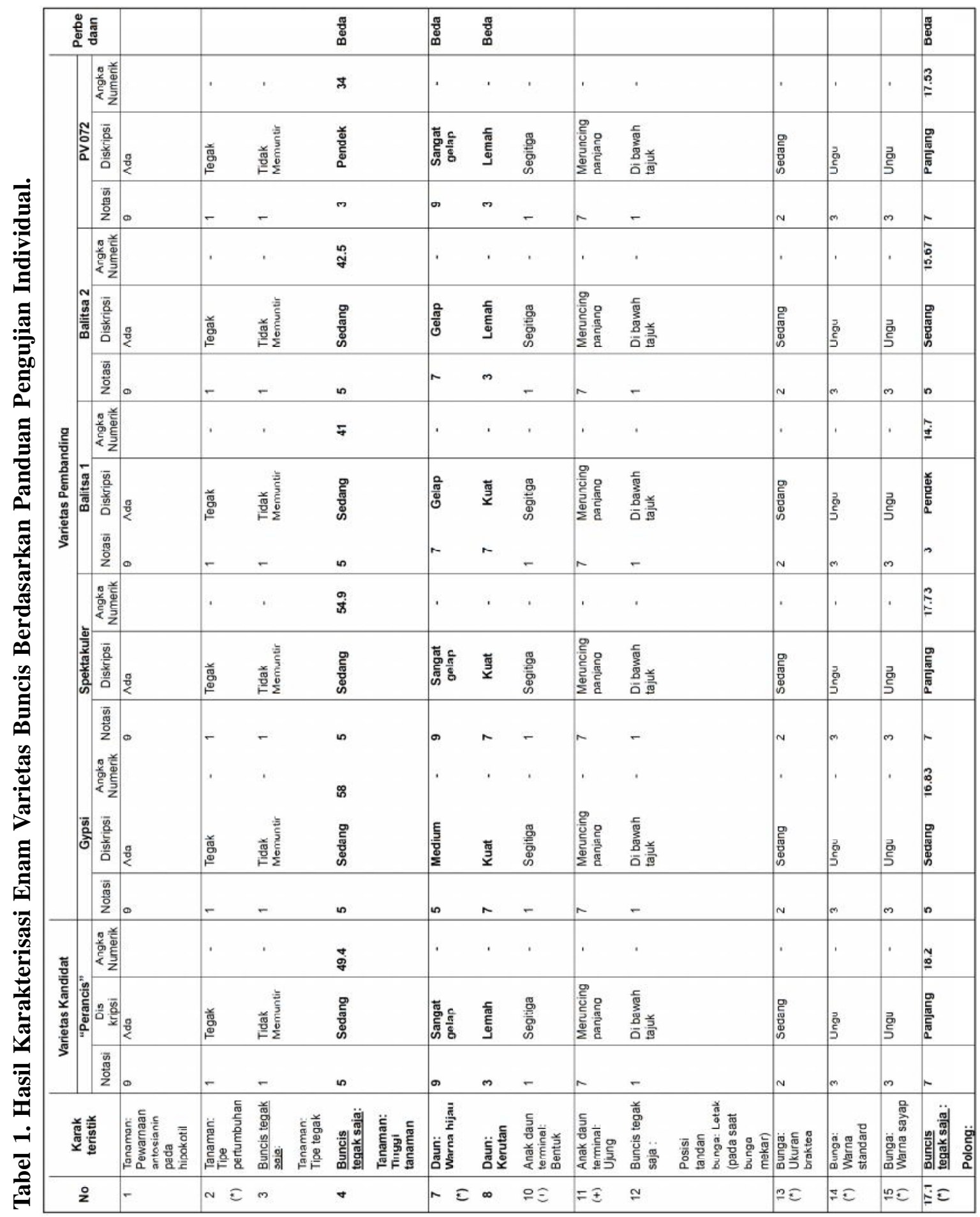




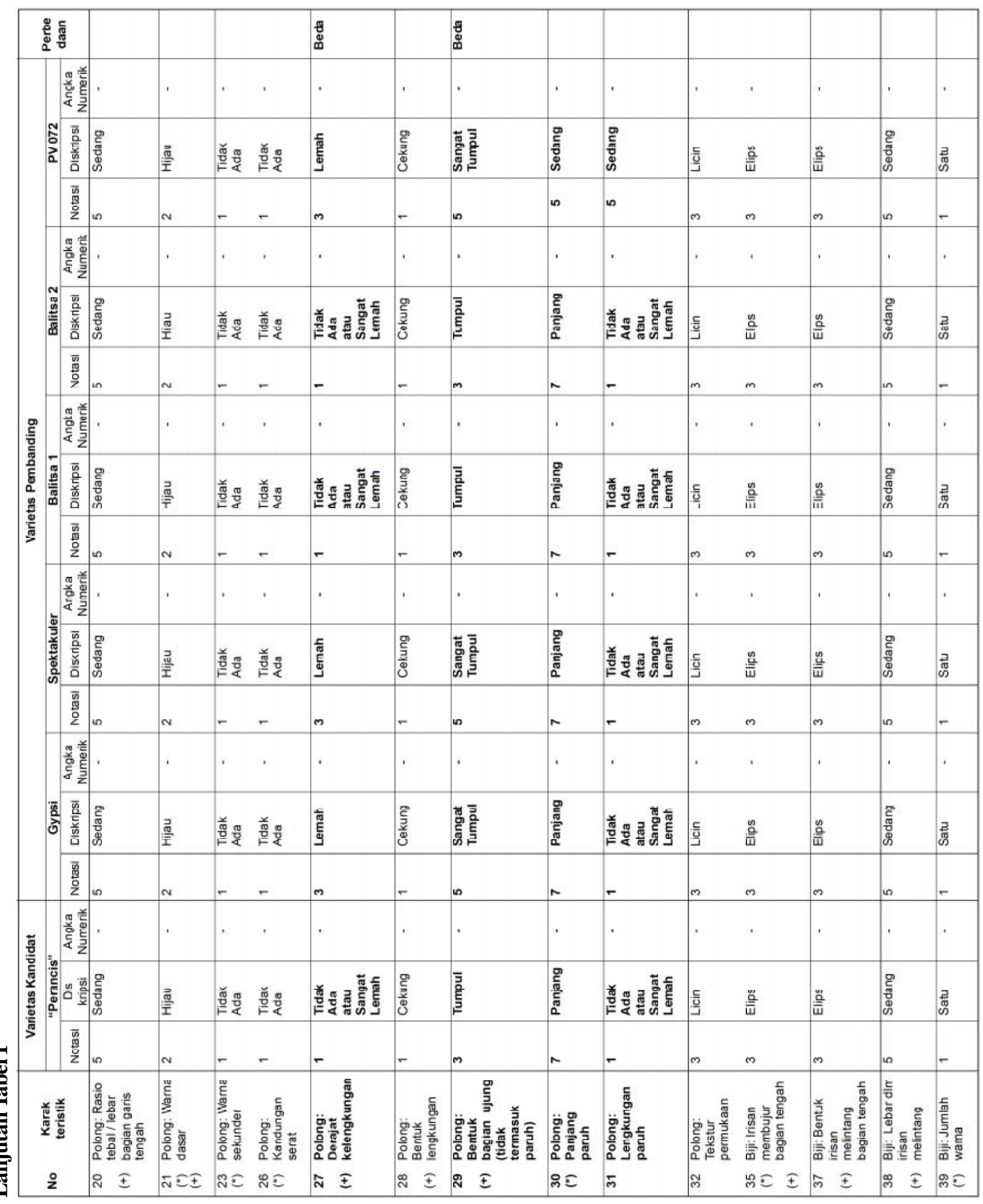




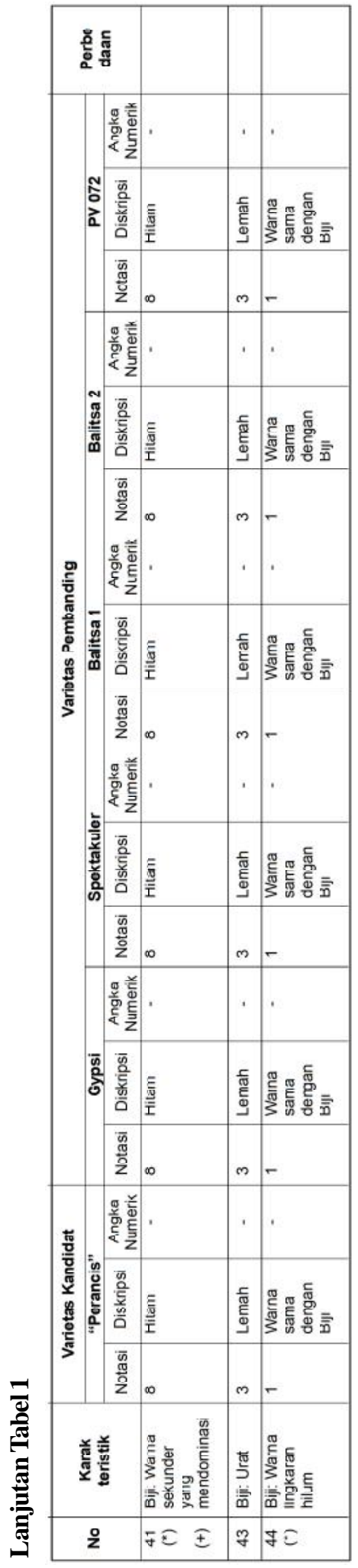


varietas Gypsi dan Balitsa 2 dengan notasi 5 (sedang) serta varietas Balitsa 1 dengan notasi 3 (pendek).

Pengujian varietas "Perancis" menunjukkan perbedaan karakter derajat kelengkungan polong tidak ada atau sangat lemah (notasi 1) yang berbeda dibandingkan dengan varietas Gypsi, Spektakuler dan PV 072 yang lemah (notasi 3).

Bentuk bagian ujung (tidak termasuk paruh) polong varietas "Perancis" adalah tumpul, berbeda dengan varietas Gypsi, Pektakuler dan PV 072 yang sangat tumpul. Panjang paruh polong varietas "Perancis" dengan notasi 7 (panjang) berbeda dengan varietas PV 072 yang menunjukkan notasi 5 (sedang). Sedangkan hasil pengamatan karakter lengkungan paruh polong varietas "Perancis" tidak ada atau sangat lemah (notasi 1) berbeda dengan varietas PV 072 sedang (notasi 5).

\section{Karakter Biji}

Penentuan varietas pembanding untuk tujuan mengetahui keunikan varietas "Perancis" adalah berdasarkan pengelompokan varietas dengan tidak ada variasi atau berbeda sedikit dalam karakter biji termasuk warna utama dan sekunder yang mendominasi biji yaitu hitam.

Hasil pengujian menunjukkan baik varietas "Perancis" maupun Gypsi, Spektakuler, Balitsa 1, Balitsa 2 dan PV 072 memiliki diskripsi karakter biji yang sama yaitu irisan membujur bagian tengah elips, bentuk irisan melintang bagian tengah elips, lebar dalam irisan melintang sedang, jumlah warna biji satu, warna utama (bagian paling besar) hitam, warna sekunder yang mendominasi hitam, urat biji lemah dan warna lingkaran hilum sama dengan warna biji.

\section{Keseragaman}

Penilaian keseragaman populasi ditetapkan standar 1 persen untuk buncis tipe tegak dengan peluang diterima 95 persen, untuk populasi 150 tanaman maka jumlah tipe simpang maksimum yang diperbolehkan adalah empat. Pada pengamatan buncis varietas "Perancis" selama dua periode pertumbuhan tidak ditemui adanya tipe simpang atau campuran varietas lain, sehingga dapat dikatakan varietas "Perancis" telah memiliki kesergaman.

\section{Kestabilan}

Penilaian kestabilan didasarkan pada masingmasing tipe varietas, jika suatu varietas telah menunjukkan keseragaman maka telah dianggap stabil. Jika diragukan dan memang diperlukan pengujian kestabilan dapat dilakukan dengan penanaman ulang pada tahun atau musim berikutnya atau menguji ulang dengan menggunakan bibit baru atau cadangan tanaman untuk menjamin bahwa materi menampilkan karakteristik yang sama seperti materi tanam sebelumnya. Pengujian yang dilakukan terhadap varietas "Perancis" dalam kondisi normal pertumbuhannya menunjukkan keseragaman maka telah dianggap stabil.

\section{KESIMPULAN}

1. Hasil pengujian berdasarkan PPI buncis menunjukkan delapan karakter keunikan varietas "Perancis" dibandingkan dengan varietas Gypsi, Spektakuler, Balitsa 1, Balitsa 2 dan PV 072 yaitu pada karakter tinggi tanaman, warna daun, kerutan daun, panjang (termasuk paruh) polong, derajat kelengkungan polong, bentuk bagian ujung (tidak termasuk paruh) polong, panjang paruh polong dan lengkungan paruh polong.

2. Varietas "Perancis" telah memiliki keseragaman dan kestabilan.

\section{DAFTAR PUSTAKA}

Anonim. 1981. Daftar Komposisi Bahan Makanan. Dirjen Gizi, Departemen Kesehatan. Bathara Karya Aksara. Jakarta. 
Departemen Pertanian. 2002. Undang-Undang Republik Indonesia Nomor 29 Tahun 2000 tentang Perlindungan Varietas Tanaman. Pusat Perlindungan Varietas Tanaman. Departemen Pertanian. Jakarta.

Djuariah, D. 2008. Penampilan Lima Kultivar Kacang Buncis Tegak di Dataran Rendah. Jurnal Agrivigor SeptemberDesember 8 (1): 64-73.

Estu. R. dan Nur B.V.A. 1994. Budidaya Potong, Pucuk dan Baby Kapri. Penebar Swadaya. Jakarta.

Kusmana dan E. Sofiari. 2007. Karakterisasi kentang varietas Granola, Atlantic dan Balsa dengan Metode UPOV. Buletin Plasma Nutfah 13 (1): 27-33.
Pinilih, J. 2005. Pewarisan Sifat Warna Bunga Ukuran Polong dan Bobot Polong Pada Persilangan Buncis (Phaseolus Vulgaris L.) Kultivar Richgreen dengan Flo.Agrosains 18 (1): 11-22.

Pusat Perlindungan Varietas Tanaman. 2007. Panduan Pengujian Individual Kebaruan, Keunikan, Keseragaman dan Kestabilan Buncis (Phaseolus vulgaris L.). PusatPerlindungan Varietas Tanaman. Jakarta.

Rismunandar. 1982. Bertanam Sayur-sayuran. Terate. Bandung.

Sunarjono, H. 2007. Bertanam 30 Jenis Sayuran. Penebar Swadaya. Jakarta. 